\title{
Laterale vs algoritmico: un nuovo (vecchio) ruolo per il disegno?
}

\author{
Marco Carpiceci \\ Fabio Colonnese
}

Abstract

" "pensiero laterale" definito da Edward De Bono implica un approccio anticonvenzionale a un problema in grado di generare soluzioni alternative, esplorare i limiti di un modello di pensiero, valutarne di alternativi e provocare uno di quei cambi di paradigma di cui parla Kuhn. In quanto filiazione diretta del pensiero divergente di Guilford, esso si fonda su capacità come la flessibilità semantica, la fluidità di associazioni, l'ideazione e la trasformazione: tutte capacità che appartengono al bagaglio e al vissuto quotidiano di un progettista della seconda metà del Novecento. La pratica fondamentale che rende possibile e naturale il perpetuarsi di questi saperi è il disegno, inteso come una pratica soggettiva, inconsapevole e istintiva ma dall'incredibile potenziale euristico e creativo. Questo contributo propone una riflessione e alcuni esercizi pratici su quello che potrebbe essere un nuovo (vecchio) ruolo del disegno in una epoca in cui l'abuso di prescrizioni, macchine e algoritmi rischia di limitare il formarsi di condizioni utili allo sviluppo di approcci e soluzioni creative, nel senso più ampio del termine.

Parole chiave

pensiero laterale, pensiero divergente, lateralizzazione, disegno, creatività.

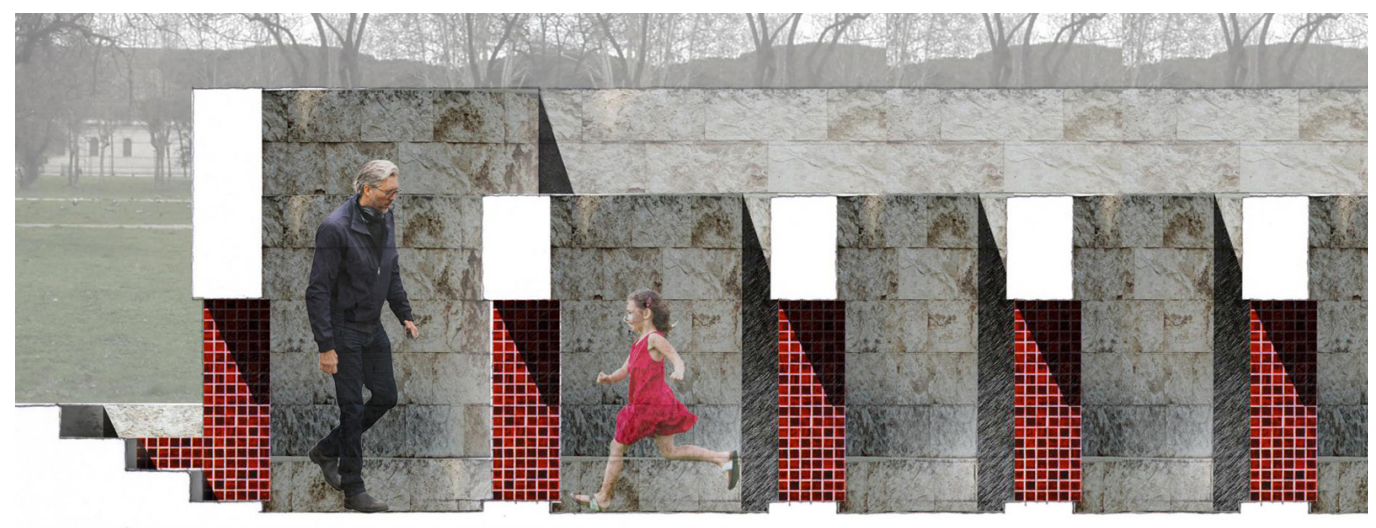




\section{II concetto}

II "pensiero laterale", definito negli anni Settanta del secolo scorso dallo psicologo maltese Edward De Bono [De Bono 1998], descrive un approccio anticonvenzionale a un problema. Prendiamo la matematica, il modello di interpretazione della realtà per eccellenza, almeno per la civiltà occidentale. La matematica contiene in sé sia gli elementi del problema, sia le chiavi per la soluzione. Così un problema di matematica si risolve generalmente in modo lineare o 'verticale', costruendo una sequenza più o meno complessa di operazioni che prende il nome di algoritmo. Al contrario, altri problemi possono eludere questo approccio diretto e richiedere una pluralità di punti di vista e di tentativi, che non rinunciano al pensiero logico ma che allargano l'orizzonte del problema stesso a interpretazioni differenti. Di più. II pensiero laterale si può applicare anche alla matematica ovvero a quei problemi che hanno già una soluzione, per generare soluzioni alternative, per esplorare i limiti di un modello di pensiero e valutarne di alternativi. L'obiettivo è quello di evadere dalla rigidità dei modelli tradizionali, di provocare uno di quei cambi di paradigma di cui parla Kuhn [Kuhn 1995] nei suoi libri. Nel suo piccolo, il progetto per un labirinto commemorativo per i Caduti di Nassiriya da costruirsi presso la basilica di S. Paolo, costituisce una applicazione 'metaforica' di questo principio: mentre gli adulti sono costretti a muoversi nelle sue spire applicando qualche algoritmo per trovare il percorso fino al centro, i bambini - e gli adulti che accettano di tornare tali, abbassando l'altezza del loro punto di vista e mettendosi carponi - possono attraversarlo in linea retta, eludendone il meccanismo di perdizione (fig. I).

Il pensiero laterale è una filiazione diretta di quello che Guilford [1959], psicologo e studioso della creatività, aveva definito il "pensiero divergente", in termini complementari a quello "convergente" ossia lineare e logico. II pensiero divergente è "I'abilità di produrre nuovi approcci e idee originali formando combinazioni imprevedibili dalle informazioni disponibili e applicando capacità come la flessibilità semantica, la fluidità di associazioni, l'ideazione e la trasformazione" [Cropley 2006, p. I].

Flessibilità nell'adottare strategie diverse e nel cambiare approccio; fluidità nel produrre associazioni libere; attitudine a formulare idee originali; trasformare le idee in fatti concreti: in fondo, il lavoro progettuale dell'architetto moderno è stato fortemente segnato da questi indirizzi programmatici, per lo più in termini inconsapevoli. Se si rilegge quanto scritto fin qui immaginando un architetto alle prese con le fasi preliminari di un progetto, intento a schizzare freneticamente su carta trasparente seduto al tavolo da disegno, si scopre che tutto sembra corrispondere a gesti e dinamiche ben note. Nella pratica progettuale dell'architetto, soprattutto nell'esperienza che appartiene agli architetti della seconda metà del secolo scorso, l'adozione di strategie e di tattiche creative oggi definite come pensiero divergente - laterale erano all'ordine del giorno. Erano parte di un sapere diffuso, di una tradizione intesa come "un universo disordinato di conoscenze e sentimenti che lega materialmente l'architettura al lavoro dell'uomo" [Braghieri 20 I3, p. 23 I] che si tramandava attraverso il lavoro di bottega e attraverso l'emulazione "in quanto somma di tutte le esperienze maturate, di tutti i saperi che hanno superato la soglia di una generazione" [Braghieri 20।3, p. 237]. L'architetto è, o sarebbe meglio dire era, quindi una sorta di portatore sano e inconsapevole di pensiero laterale.

La pratica fondamentale che rendeva possibile e naturale il perpetuarsi di questi saperi è il disegno, inteso come una attività soggettiva inconsapevole, istintiva ed euristica, nella quale si alternano continuamente gesti creativi e atti analitici, momenti di catalogazione e di approfondimento e, soprattutto, cambi di scenario, di approccio, di geometrie, di punto di vista, di tecnica di rappresentazione, di interlocutore, di materiali, di priorità, di senso. In qualche modo, uscire da quella che oggi si chiama comfort zone era parte della tradizione stessa. Pensiamo solo alle strategie elaborate dagli architetti per superare crisi, empasse e problemi progettuali apparentemente irrisolvibili, come quella di Alvar Aalto, che semplicemente smetteva di ragionarci e iniziava a dipingere uno dei suoi meravigliosi quadri astratti. Altrettanto si potrebbe dire delle 'tecniche di apertura' di un nuovo progetto: Antoine Predock deve 'possedere' il sito del progetto disegnandolo con materiali di scarto trovati sul posto stesso laddove Alvaro Siza Viera inizia a disegnare senza neanche aver visto il luogo 
o il programma per costituire una sorta di catalizzatore visivo apriori utile a promuovere gli sviluppi successivi.

In questi anni gli strumenti di lavoro tradizionali sono stati abbondantemente sostituiti da macchine e algoritmi che mediano e indirizzano in termini preordinati e prettamente visivi lo sviluppo del pensiero creativo e che ostacolano l'interlocuzione e lo scambio. Tali strategie e tattiche 'insite' nella tradizione sono state 'oggettivizzate' ed 'esternalizzate', diventando materia di studio e di sperimentazione 'supplementare' per stimolare la creatività, l'innovazione e il problem solving tanto richiesti dalla competitiva società del consumo.

\section{L'ambiente e il corpo}

Per recuperare i fondamenti della pratica 'creativa' occorre operare su due livelli paralleli: l'ambiente culturale e il rapporto tra mente e corpo. In primo luogo, occorre predisporre un contesto operativo assai diverso da quello attuale: occorre cioè uscire dall'equivoco indotto dalla tecnica. Questo "luogo della razionalità assoluta", come scrive Galimberti [Galimberti 1999], ha insinuato l'idea che l'uomo debba confrontarsi con la "macchina" e che il suo ruolo e la sua stessa identità sociale debbano essere giudicati esclusivamente in termini di burocrazia, efficienza e organizzazione. Occorre invece predisporre un ambiente, e l'università è fondamentale in questo scenario, dove poter collaborare e condividere, senza pensare ai colleghi come a degli antagonisti; dove sbagliare sia normale anzi sia necessario, in quanto vero sintomo di un processo creativo; dove essere stimolati a pensare fuori dai

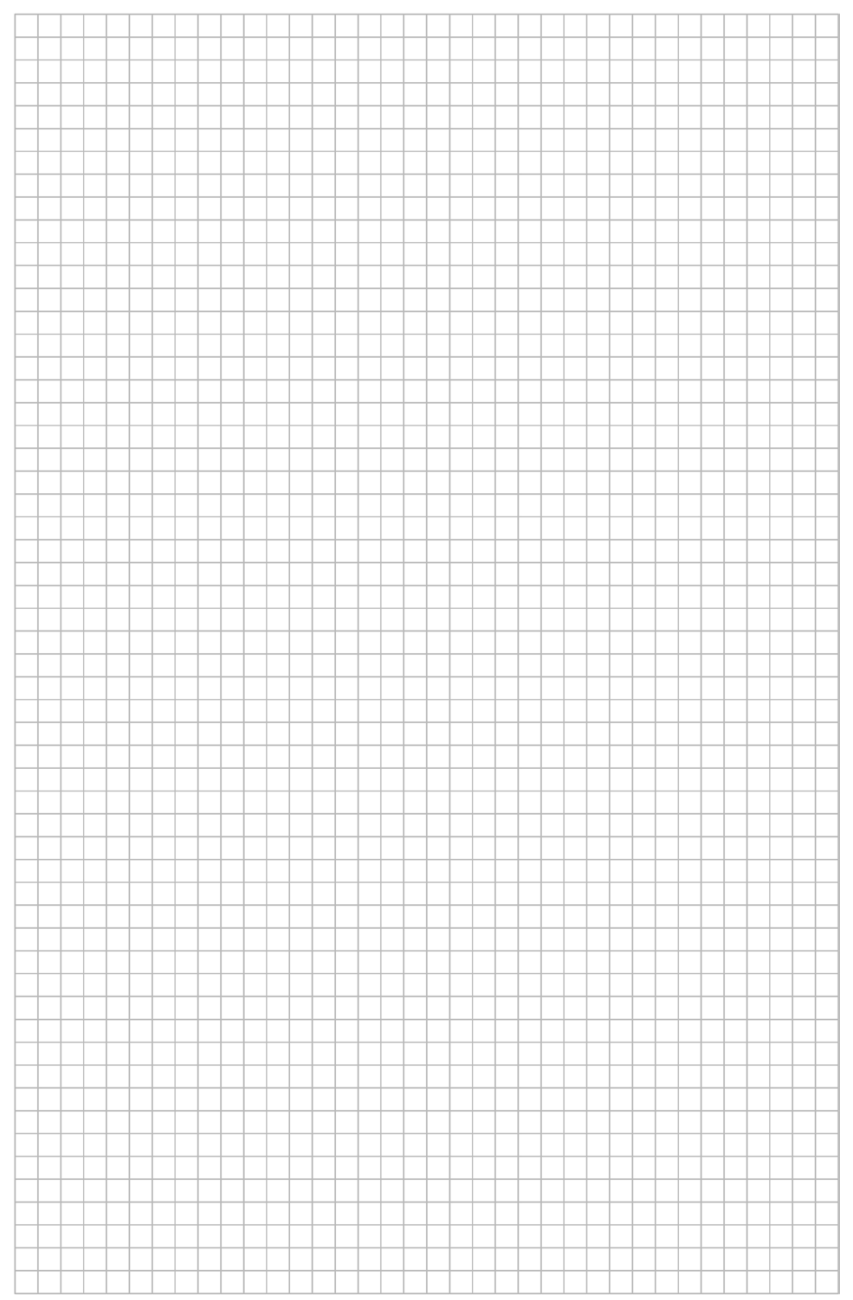


percorsi preordinati, fuori dai limiti imposti da macchine e algoritmi, anche attraverso tecniche di hacking e di eversione creativa utili a manifestare le potenzialità e i limiti stessi del vivere sociale.

In secondo luogo, è fondamentale il recupero di un ruolo centrale del corpo e una nuova educazione a sensazioni, percezioni, sentimenti che sembrano sempre più fuori posto nella collettiva esaltazione per tutto ciò che è virtuale. E il disegno tradizionale può svolgere magnificamente questo compito, soprattutto cercando di ristabilire un nesso funzionale fluido tra cervello, occhio e mano. Per impadronirsi del pensiero laterale è importante combattere la 'lateralizzazione', sia in termini metaforici, in quanto abitudine ad affrontare le questioni sempre dal medesimo punto di vista, sia in termini psico-fisici. La 'lateralizzazione' è quella caratteristica che si sviluppa tra i 3 e gli 8 anni di vita e che vede lo stabilizzarsi del comportamento motorio in funzione della scelta di un lato, destro o sinistro che sia. Questo avviene quindi in tutte le attività asimmetriche nelle quali si utilizza un solo arto e naturalmente poi si tende a utilizzare sempre quella 'lateralità'. Questa scelta naturale però tende a determinare sempre un lato 'pigro' che invece può essere conservato vivo ed efficiente attraverso un utilizzo 'simmetrico', senza per questo 'disconoscere' la maggiore abilità dell'uno rispetto all'altro.

La 'palestra' del disegno offre l'opportunità di allenare entrambe le 'lateralità', perfettamente coscienti che la più abile verrà utilizzata di preferenza ma che anche l'altra potrà trasmetterci le proprie sensazioni - al punto che alcuni disegni preferiremo eseguirli con lei perché è quello il tipo di sensazione che preferiremo in quello specifico caso.

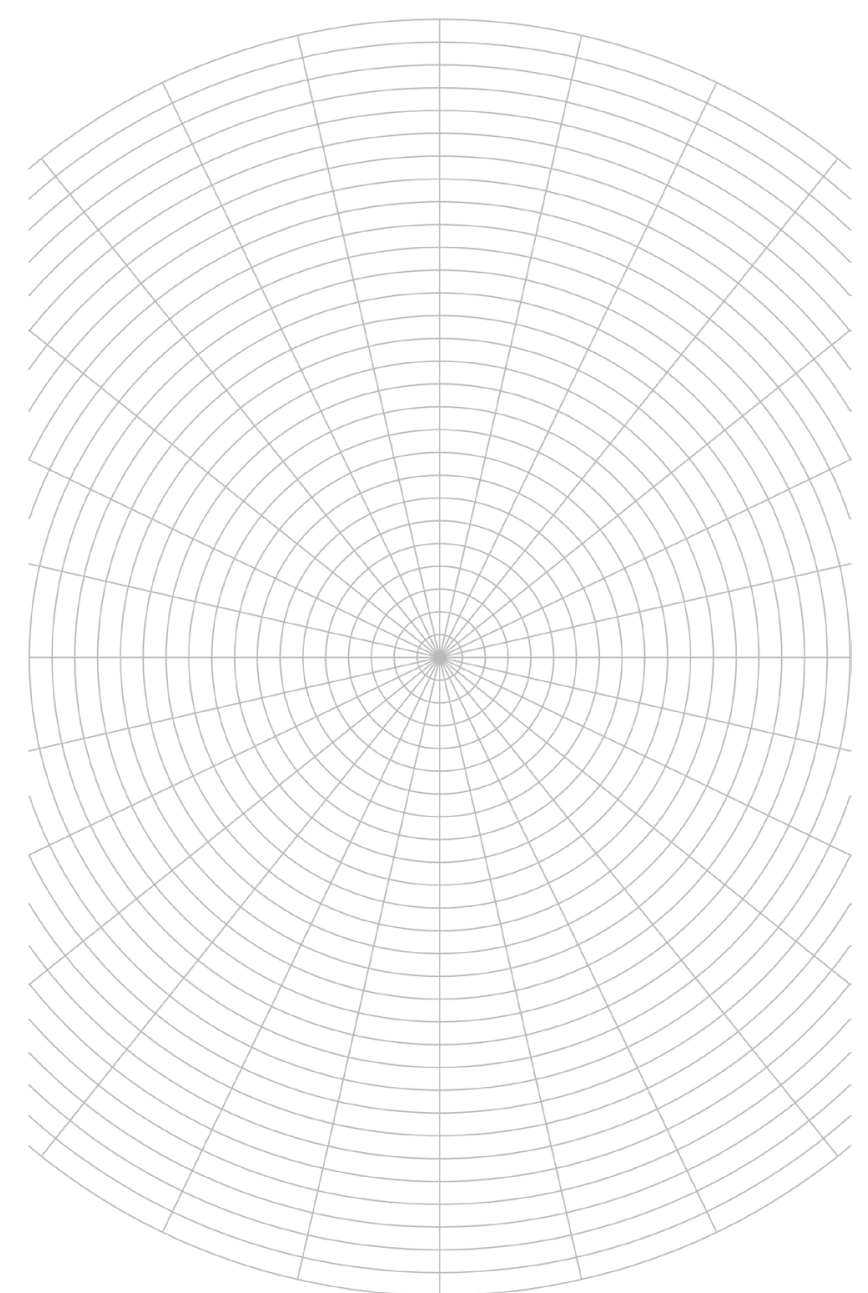


Ogni attività fisica, com'è, in parte, il disegno, ha bisogno di una adeguata preparazione che renda fluidi, naturali e automatici quei gesti che compongono l'attività stessa. È quindi opportuno, anche se scarsamente applicato, praticare delle semplici operazioni che abituino il corpo a compiere i gesti del disegno, di modo che, interiorizzandoli, non impegnino più l'attenzione e trasformino il disegno in una naturale espressione del pensiero.

\section{L'esercizio fisico: un esempio elementare}

Anche quando si è lontani dal momento esecutivo, è utile praticare dei 'riscaldamenti' per tenere esercitato il corpo a compiere quelle semplici operazioni che sono alla base di una buona capacità grafica. L'esercizio qui proposto, elaborato nell'ambito del corso di Disegno dell'Architettura alla Facoltà di Ingegneria della Sapienza di Roma, serve ad aumentare il controllo nel tracciamento di segni innaturali, come le linee rette o le circonferenze, che sono istintivamente antitetici alla struttura della mano stessa, che invece, essendo organizzata intorno a delle giunture rotanti nelle dita, nel polso e nel gomito, ha l'attitudine a produrre gesti curvi e variabili.

L'esercizio dovrà essere eseguito con entrambe le mani, una volta con la destra e una con la sinistra. II fatto che siamo destri o mancini è quindi irrilevante. Lo scopo generale non è però formare disegnatori ambidestri ma semplicemente abituare la nostra fisicità a non creare parti 'pigre' dandoci così la possibilità di decidere consapevolmente (o indifferentemente) a quale lato ricorrere, e in quale momento, per esprimerci con il disegno.

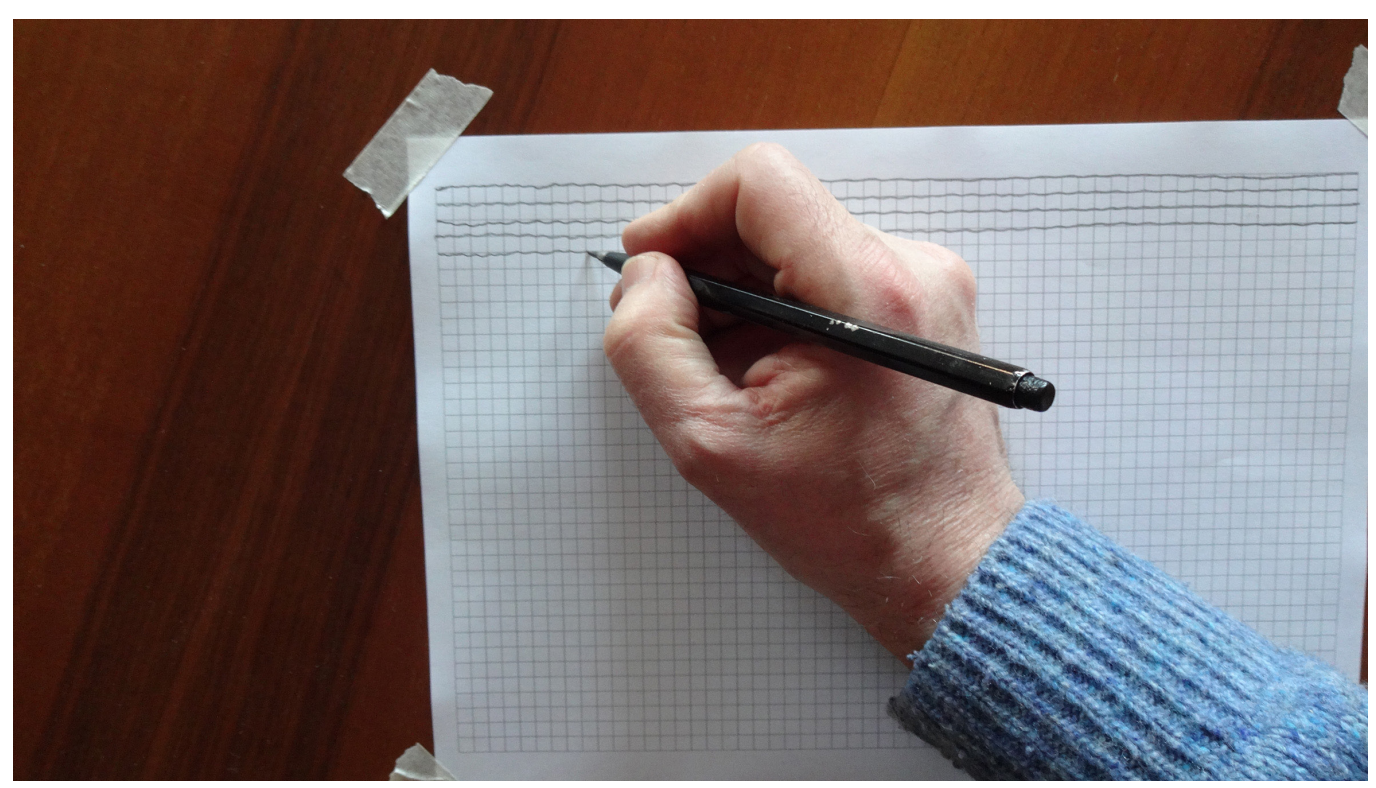

Si inizierà con una serie di disegni con 'linee vincolate', ossia delle linee prestampate da seguire con lo sguardo e con la mano assieme. In questa maniera si obbligherà la mano ad abituarsi all'estensione regolare, rettilinea o curvilinea, e involontariamente tutti i movimenti verranno acquisiti e si sedimenteranno nel corpo. Successivamente si passerà a una serie di disegni con 'linee in campo aperto', ossia al tracciamento delle stesse griglie mediante, però, la presenza di pochi riferimenti. In questa maniera si distoglierà l'attenzione da un'area puntuale a una di maggiore dimensione.

Vediamo nel dettaglio il primo di questi esercizi e poniamoci nelle condizioni del maestro che lavora gomito a gomito con l'allievo. 
Laviamo le mani e asciughiamole. Sediamoci su di una sedia ben solida, sistemata di fronte a una scrivania sgombra. Prendiamo un foglio di carta a quadretti grandi (5 $\mathrm{mm}$ di lato) di formato ISO A4 (cm $21 \times 29,7)$ da $80 \mathrm{~g} / \mathrm{mq}$; disponiamolo davanti a noi in orizzontale (landscape) fissandolo per gli spigoli al tavolo con della carta gommata (lo scotch beige opaco). Se il piano è scabroso o troppo duro potremo appoggiare il foglio su un cartoncino o su altri fogli. L'importante è che non deve essere mosso per alcun motivo. II foglio a quadretti servirà per i primi esercizi, e agevolerà il tracciamento di linee parallele e perpendicolari. In seguito, useremo fogli bianchi e successivamente passeremo a cartoncini da disegno da almeno $120 \mathrm{~g} / \mathrm{mq}$ lisci che permetteranno di affinare la precisione.

Per convenzione eseguiremo gli esercizi prima con la mano destra e poi con la sinistra; una volta acquisita la padronanza dei movimenti, potremo decidere noi con quale mano cominciare. Prendiamo ora una matita di legno, meglio un portamine, con una grafite di media durezza, una HB, e temperiamone la punta. Come impugnare la matita? La parte della punta deve trovarsi appoggiata sul punto medio dell'ultima falange del dito medio e tenuta contemporaneamente dai polpastrelli dell'indice e del pollice. La matita deve 'uscire' dalla mano (verso il dorso) appoggiandosi alla falange del palmo subito al di sotto della nocca dell'indice, a metà tra pollice e indice. La punta sporgerà dalle dita di circa $2 \mathrm{~cm}$.

La postura è importante, come per mangiare o per suonare il pianoforte, il liuto o la chitarra; ci posizioniamo con il busto eretto e senza avvicinarci al foglio con la testa e senza arcuare la spina dorsale verso il foglio.

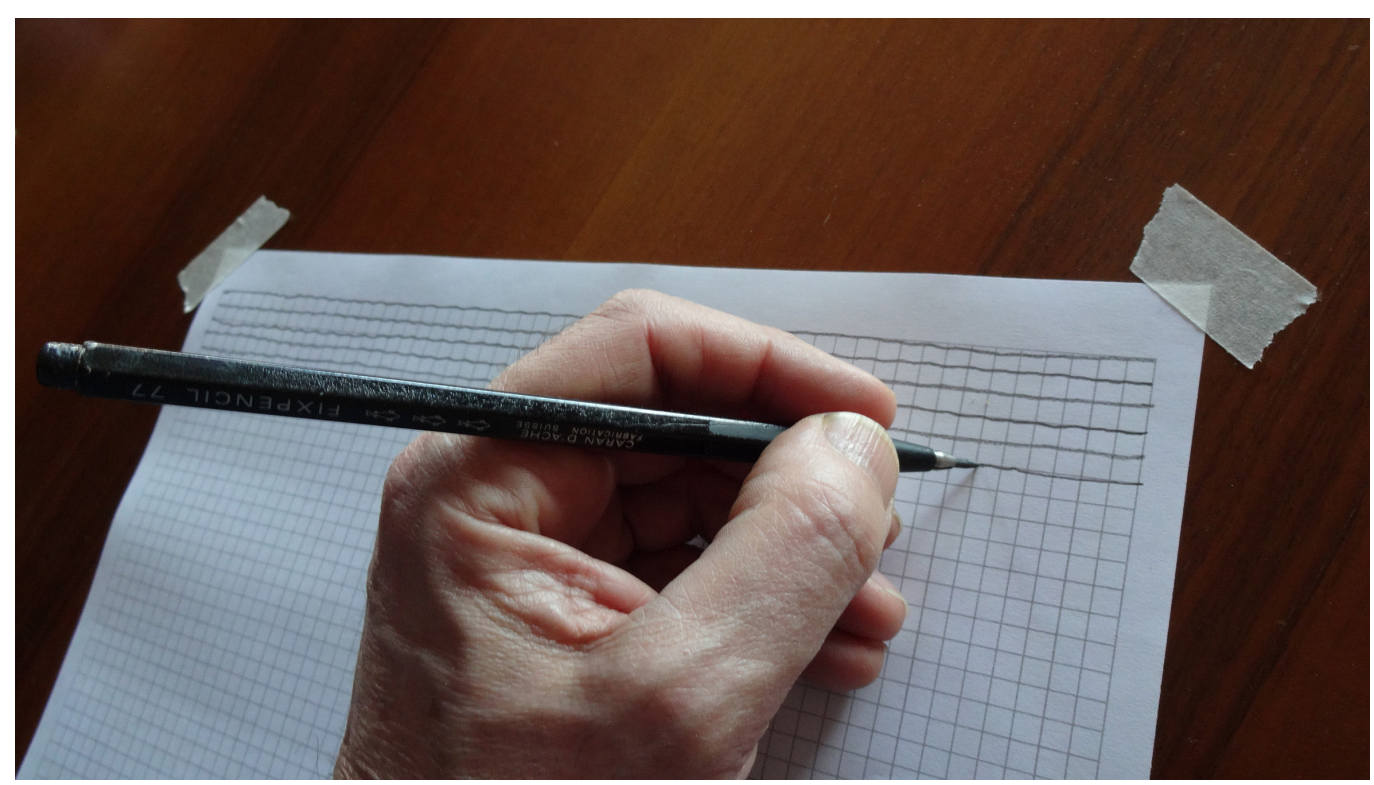

II tracciamento migliore è centrifugo, come quando si scrive, e questo per far sì che la mano non strofini il foglio sulla linea appena tracciata. La posizione della mano però deve anche agevolare l'osservazione della linea che si sta tracciando, sia nella parte tracciata sia in quella ancora da tracciare. Questa condizione non è sempre realizzabile e quindi bisognerà orientare il polso in maniera da trovare un compromesso utile alla migliore osservazione. Nel tracciamento con mine molto appuntite (soprattutto per quelle dure) ci si potrebbe trovare nella condizione di dover tracciare una linea in verso contrario a quello centrifugo, e quindi ci troveremmo con la punta nella tendenza di bucare il foglio. In questo caso la rotazione del polso ci può fornire una posizione migliore per il controllo visivo della retta che stiamo tracciando e contemporaneamente evitare l'impuntarsi della mina.

Soprattutto con le mine più morbide, la mano dovrà essere sempre pulita e secca per non spargere grafite al passaggio su altri segni. In alcuni casi è opportuno l'utilizzo di un secondo 
piccolo foglio da adoperare come appoggio mobile della mano ed evitare macchie indesiderate.

Iniziamo con il tracciamento più semplice, le 'linee orizzontali'. Partiamo dall'angolo in alto a sinistra e tracciamo la prima linea verso destra, scendiamo di $5 \mathrm{~mm}$ e tracciamo la successiva in direzione inversa, da destra verso sinistra, e così via sino al completamento del foglio. Passiamo poi alle 'linee verticali'. Sempre partendo dall'angolo superiore sinistro tracciamo verso il basso la prima linea, ci spostiamo a destra di $5 \mathrm{~mm}$ e percorriamo la seconda linea in senso inverso dal basso verso l'alto; e così fino al completamento del foglio.

Ogni linea deve essere percorsa interamente cercando di non staccare la punta dal foglio. La pressione deve essere costante e l'andamento continuo e rettilineo, non veloce né lento ma costante. L'attenzione deve essere prestata al seguire le linee stampate e non al guardare la punta, cercando cioè di concentrarsi sul tratto che si sta tracciando.

A ogni linea dovremo avere l'accortezza di far ruotare leggermente la matita. Questa operazione contribuirà a mantenere alla matita una terminazione sferica che renderà i segni di spessore costante per più tempo. Sarà comunque necessario ogni tanto fermarci a rifare la punta alla matita.

Nuovo foglio e cambio mano, ora con la sinistra, tutto specchiato. Orizzontali dall'angolo in alto a destra, da destra verso sinistra, e via di seguito invertendo il verso a ogni linea. Verticali sempre dall'angolo in alto a destre, dall'alto verso il basso e a seguire invertendo verso. Ripetendo più volte queste operazioni si accorgeremo che le linee tenderanno a essere sempre più vicine alle rette stampate, saranno anche più uniformi e meno tremolanti: sarà giunto quindi il momento di passare ai fogli bianchi.

Questa sorta di preludio al disegno come palestra per il corpo e la mente, con tutta la disciplina fisica e mentale che richiede, è solo un esempio di una ampia serie di esercizi su cui gli autori stanno lavorando concepiti per far uscire gli allievi dalla loro comfort zone, contribuisce ad affrancarsi dalla dipendenza della lateralità e ad affrontare qualsiasi questione in termini laterali, divergenti, creativi, proprio come un architetto.

\section{Non banalizziamo}

Come spiega Di Napoli [Di Napoli 2004], il disegno ha una dimensione interculturale, interlinguistica e simbolica che è il frutto di una discretizzazione e di una sintesi della complessità del pensiero. Ogni atto di osservazione della realtà o di ideazione ha come momento successivo la rappresentazione dei suoi aspetti caratterizzanti. Attraverso gli occhi si percepisce il segno che si trasforma di nuovo in pensiero e attraverso il disegno la mente genera immagini e instaura un flusso iterativo di 'sogni' e di 'segni': un flusso continuo di cui bisogna esercitare ed esperire la sensazione emotiva dello scorrere in maniera non finalizzata o strumentale, come le azioni di un bambino che semplicemente imita gli adulti. Come suggerisce Goleman: "Riuscire a entrare nel flusso è la massima espressione dell'intelligenza emotiva; il flusso rappresenta forse il massimo livello di imbrigliamento e sfruttamento delle emozioni al servizio della elementare semplicità e nella resistenza e difficoltà che incontra negli studenti dimostra implicitamente gli effetti negativi di un ambiente omologante e plasmato su misura dell'algoritmo 'vincente'. Disegnare con la mano diversa dalla nostra lateralità non è un'operazione banale e promuove un'involontaria acquisizione di un flusso cognitivo che allena il nostro cervello a spostare l'equilibrio cognitivo anche in termini emotivi, a divenire quindi più 'inclusivi' rispetto all'ambiente" [Goleman 1996, p. I55]. E come afferma Perkins: "le soluzioni sorprendono perché comportano molto spesso una fuga da un'oasi della falsa promessa [...] verso una soluzione di un tipo molto diverso dal previsto" [Perkins 200 I, p. 88] [I].

\section{Note}

[I] II paper è frutto del lavoro collegiale dei due autori. Le prime due parti sono state editate da Colonnese e le rimanenti da Carpiceci. 


\section{Riferimenti bibliografici}

Braghieri Nicola (2013). Architettura, arte retorica. Genova: Sagep Editori.

Cropley Arthur (2006). In praise of convergent thinking. In Creativity Research Journal, I 8, pp. 39 I-404.

De Bono Edward (1998). Creatività e pensiero laterale. Milano: Rizzoli.

Di Napoli Giuseppe (2004). Disegnare e conoscere. Torino Einaudi.

Galimberti Umberto (1999). Psiche e techne. L'uomo nell'età della tecnica. Bologna: Feltrinelli.

Goleman Daniel (1996). Intelligenza emotiva. Milano: Rizzoli.

Guilford Joy Paul (1959). Traits of creativity. In Anderson Harold Homer, Creativity and its Cultivation. New York: Harper, pp. I 42 - I 6 I.

Kuhn Thomas S. (1995). La struttura delle rivoluzioni scientifiche. Torino: Einaudi.

Perkins David (200 I). Come Leonardo. Milano: II Saggiatore.

Autori

Marco Carpiceci, Sapienza Università di Roma, marco.carpiceci@uniromal.it

Fabio Colonnese, Sapienza Università di Roma, fabio.colonnese@uniromal.it

Per citare questo capitolo: Carpiceci Marco, Colonnese FAbio (2020). Laterale vs algoritmico: un nuovo (vecchio) ruolo per il disegno?/Lateral vs algorithmic: a new (old) role for drawing? In Arena A., Arena M., Brandolino R.G., Colistra D., Ginex G., Mediati D., Nucifora S., Raffa P. (a cura di). Connettere. Un disegno per annodare e tessere. Atti del $42^{\circ}$ Convegno Internazionale dei Docenti delle Discipline della Rappresentazione Connecting. Drawing for weaving relationships. Proceedings of the 42th International Conference of Representation Disciplines Teachers. Milano: FrancoAngeli, pp. 260-275. 


\title{
Lateral vs Algorithmic: a New (Old) Role for Drawing?
}

\author{
Marco Carpiceci \\ Fabio Colonnese
}

\section{Abstract}

The "lateral thinking" defined by Edward De Bono implies an unconventional approach to a problem capable of generating alternative solutions, exploring the limits of a thought model, evaluating alternatives and provoking one of those paradigms shifts Kuhn wrote about. As a direct filiation of Guilford's divergent thinking, it is based on skills such as semantic flexibility, fluidity of associations, ideation and transformation: all skills that belong to the formative background and daily life of a designer of the second half of the twentieth century. The fundamental practice that makes the perpetuation of this knowledge possible and natural is drawing, intended as a subjective, unconscious and instinctive practice but with an incredible heuristic and creative potential. This contribution offers a reflection and some practical exercise on what could be a new (old) role of drawing in an era in which the abuse of prescriptions, machines and algorithms risks limiting the formation of conditions useful for the development of creative approaches and solutions, in the broadest sense of the term.

Keywords

lateral thinking, divergent thinking, lateralization, drawing, creativity.

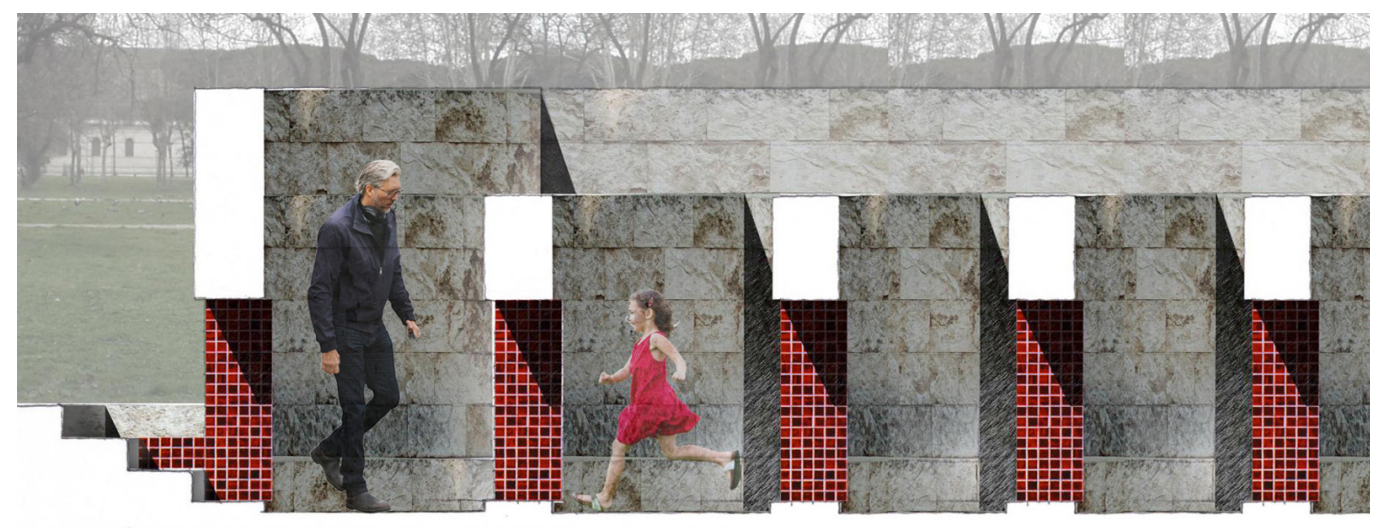




\section{The concept}

"Lateral thinking", as defined in the 1970s by the Maltese psychologist Edward De Bono [De Bono 1998], implies an unconventional approach to a problem. Let's take mathematics, the model of interpretation of reality par excellence, at least in Western civilization. Mathematics contains both the elements of the problem and the keys to the solution. Thus, a math problem is generally solved in a linear or 'vertical' way by constructing a more-or-less complex sequence of operations which is called an algorithm. Conversely, other problems may evade this linear approach and require a plurality of points of view and attempts, which do not do without logical thinking but expand the horizon of the problem itself to different interpretations. More. Lateral thinking can also be applied to mathematics or to those problems that already have a solution, to generate alternative solutions, to explore the limits of a model of thought and evaluate alternative ones. The goal is to escape from the rigidity of traditional models and to provoke one of those paradigm shifts described by Kuhn [Kuhn 1995] in his books.

Although a small example, the design of a commemorative labyrinth for the Fallen of Nassiriya to be built by the Basilica of St. Paul, Rome, constitutes a 'metaphorical' application of this principle: while adults are forced to move in its corridors by applying some mental algorithm to find the route to the center, children -and adults who agree to return as such, lowering their point of view and getting on all fours- can cross it in a straight line, eluding its losing mechanism (fig. I).

Lateral thinking is a direct filiation of what Guilford [Guilford 1959], a psychologist and scholar of creativity, defined in 1959 as "divergent thinking", in complementary terms to the "convergent" one, which is linear and logical. Divergent thinking is "the ability to produce new approaches and original ideas by forming unexpected combinations from available information and by applying such abilities as semantic flexibility, and fluency of association, ideation, and transformation" [Cropley 2006, p. I].

Flexibility in adopting different strategies and in changing approaches; fluidity in producing free associations; aptitude for formulating original ideas; transforming ideas into concrete facts: after all, the design practice of the modern architect has been strongly marked by these programmatic guidelines, mostly in unconscious terms. If we re-read what has been written so far, imagining an architect sitting at the drawing board frantically sketching on transparent paper, struggling with the preliminary stages of a project, it turns out that everything seems to correspond to well-known gestures and dynamics. In the architect's design practice, especially in the experience that belongs to the architects of the second half of the last century, adopting of creative strategies and tactics today described as lateral or divergent, were on the agenda. They were part of a widespread knowledge, of a tradition intended as "a disordered universe of knowledge and feelings that physically links architecture to the work of man" [Braghieri 2013, p. 23 I] that was handed down through the workshop work, through emulation "as the sum of all the experiences gained, of all the knowledge that has passed the threshold of a generation" [Braghieri 2013, p. 237].

Architects are, or better 'were', a sort of unaware, healthy carrier of "lateral thinking".

The fundamental practice that made the perpetuation of these knowledge possible and natural was the drawing, understood as an absolutely subjective, unconscious, instinctive, and heuristic practice, in which creative gestures alternate to analytical acts; cataloging moments alternate the deepening ones; and, above all, there are changes of scenery, of approach, of geometries, of point of view, of representation technique, of interlocutor, of material, of priority, of sense. Somehow, getting out of what is now called 'comfort zone' was part of the tradition itself. Only think of the strategies developed by the architects to overcome the crisis and impasse of a seemingly unsolvable design problem. For example, Alvar Aalto simply stopped thinking about it and started painting one of his wonderful abstract paintings. The same could be said of the techniques for opening a new project. One can mention Alvaro Siza Viera who begins to draw without even having seen the place or the program, to constitute a sort of a priori visual catalyst useful for promoting subsequent developments; or Antoine Predock, who instead must first know the site of the project and draw it with waste materials found on the site itself. 
Today, that traditional work tools have been abundantly replaced by machines and algorithms that mediate and address the visual development of creative thinking in rigid, preordered terms and that hinder dialogue and exchange, those strategies and tactics have been objectified, becoming a matter of study and experimentation to stimulate creativity, innovation and problem solving so requested by the competitive society of consumes.

\section{Environment and body}

To recover the fundaments of the 'creative' practice we have to work on two parallel levels: the cultural environment and the relationship between body and mind. First, a very different operating context has to be arranged. We need to get out of the misunderstanding induced by the Technique. This "place of absolute rationality", as Galimberti defines it [Galimberti 1999], has insinuated the idea that men and women must confront the machine and that their role and identity is to be judged exclusively in terms of bureaucracy, efficiency and organization. Conversely, a different environment, and the university is fundamental in this sense, is needed in which one can collaborate and share, without thinking of colleagues as

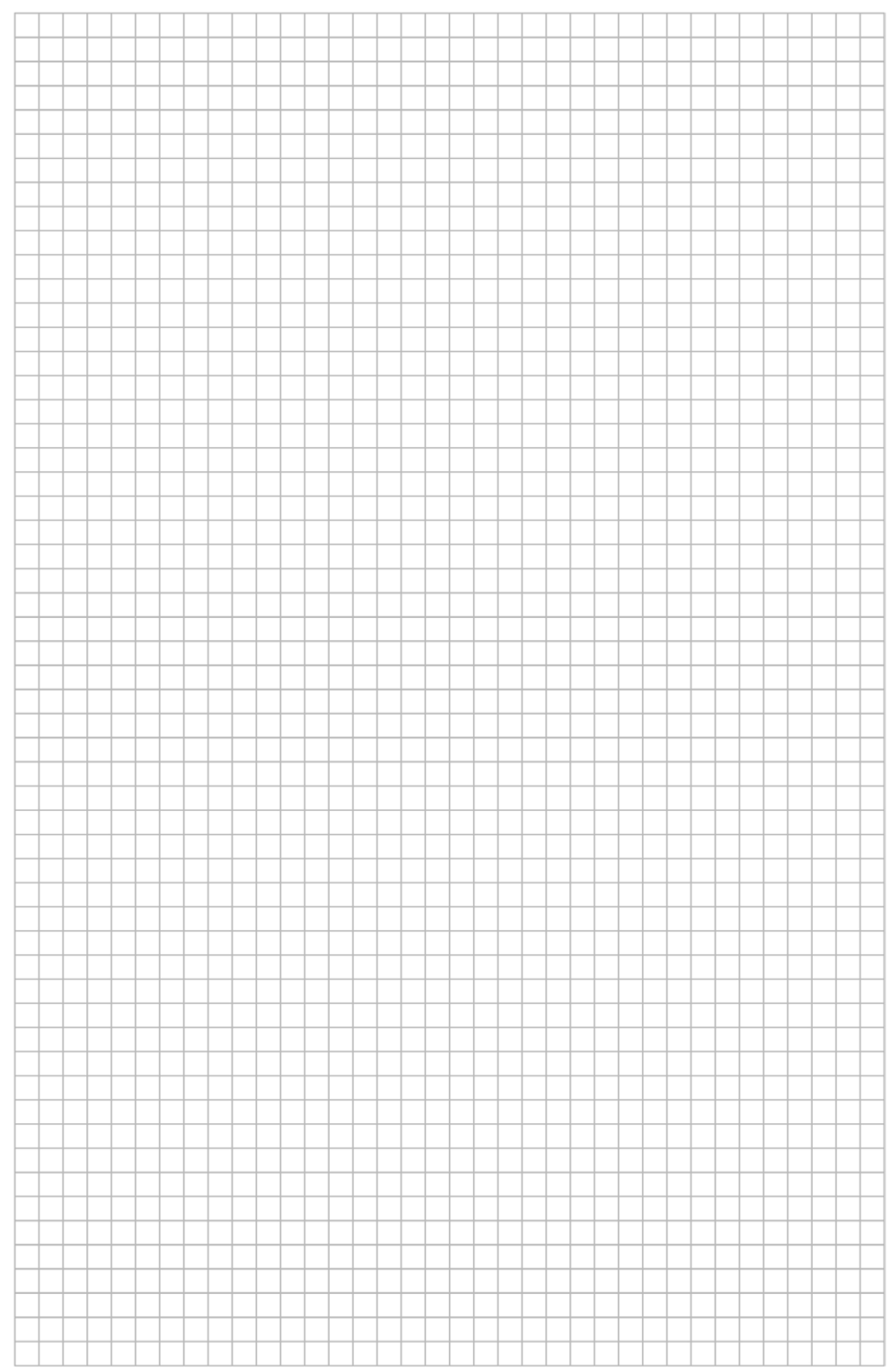


competitors; where making mistakes is normal or even necessary, as a true symptom of a creative process; where one can think outside the preordained paths, outside the limits imposed by machines and algorithms (and companies), also by stimulating hacking and creative subversion techniques useful to manifest the potentials and limits of social life itself.

Second, it is fundamental the recovery of a central role of the body and an education to sensations, perceptions, and feelings that seem increasingly out of place in the collective exaltation for all that is virtual. Manual drawing can perform this task magnificently, above all by trying to re-establish a functional connection between brain, eye and hand.

Mastering lateral thinking involves fighting [lateralization], both in metaphorical terms, as the aptitude of dealing with issues always from the same point of view, and in psycho-physical terms. Being a characteristic that develops between 3 and 8 years of life, lateralization causes the stabilization of motor behavior according to the choice of one side, right or left. This therefore occurs in all asymmetric activities in which only one limb is used. From that moment on, one always tends to use that side. This natural choice, however, tends to determine a 'lazy' side that can instead be kept alive and efficient through a symmetrical use, without neglecting the greater ability of one compared to the other.

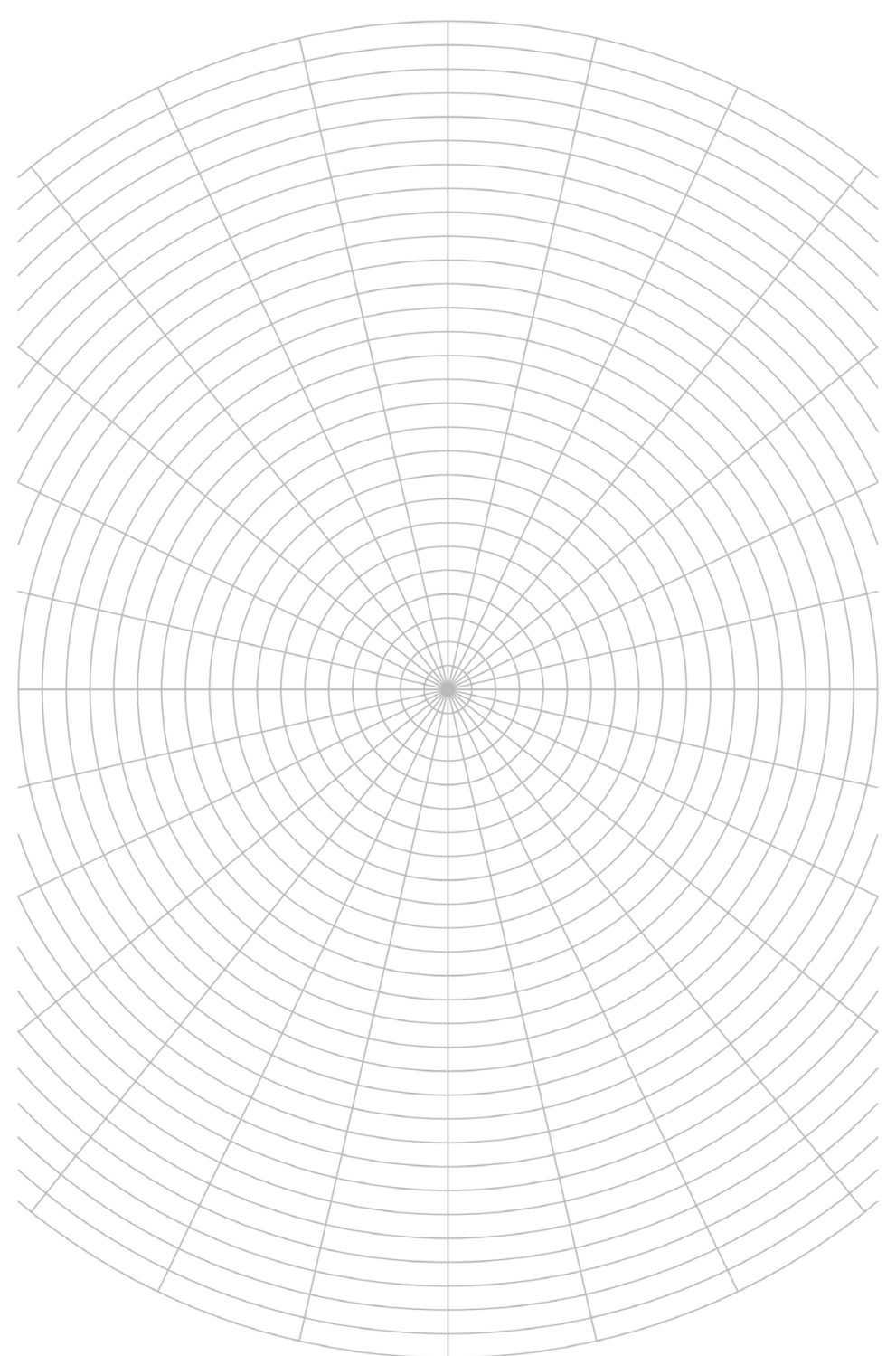


Aware that the most skilled side will be used in preference, it is essential to train both sides in the act of drawing, as the weaker side will be able to transmit specific feelings to us - to the point that in some specific cases, one would rather use the latter because of the emotional feed-back.

Every physical activity, as drawing partially is, needs adequate preparation that makes the gestures that make up the activity fluid, natural and automatic. It is therefore always advisable, even if poorly applied, to warm-up through simple operations that accustom the body to perform the drawing gestures, in order to internalize them, to let them engage no attention and to turn drawing into a spontaneous, unmediated expression of thought.

\section{Physical exercise: an elementary tutorial}

It is useful, every now and then, even away from the executive moment, to keep the body exercised to perform simple operations that are the basis of a good graphic ability. The exercises proposed here, which have been planned in the course of Drawing of Architecture in the Sapienza Faculty of Engineering, Rome, serve to increase control in tracing 'unnatural' signs, such as straight lines or circumferences, which are instinctively antithetical to the structure of the hand itself, which conversely, being organized around rotating joints in the fingers, wrist and elbow, has the ability to trace curved and variable gestures.

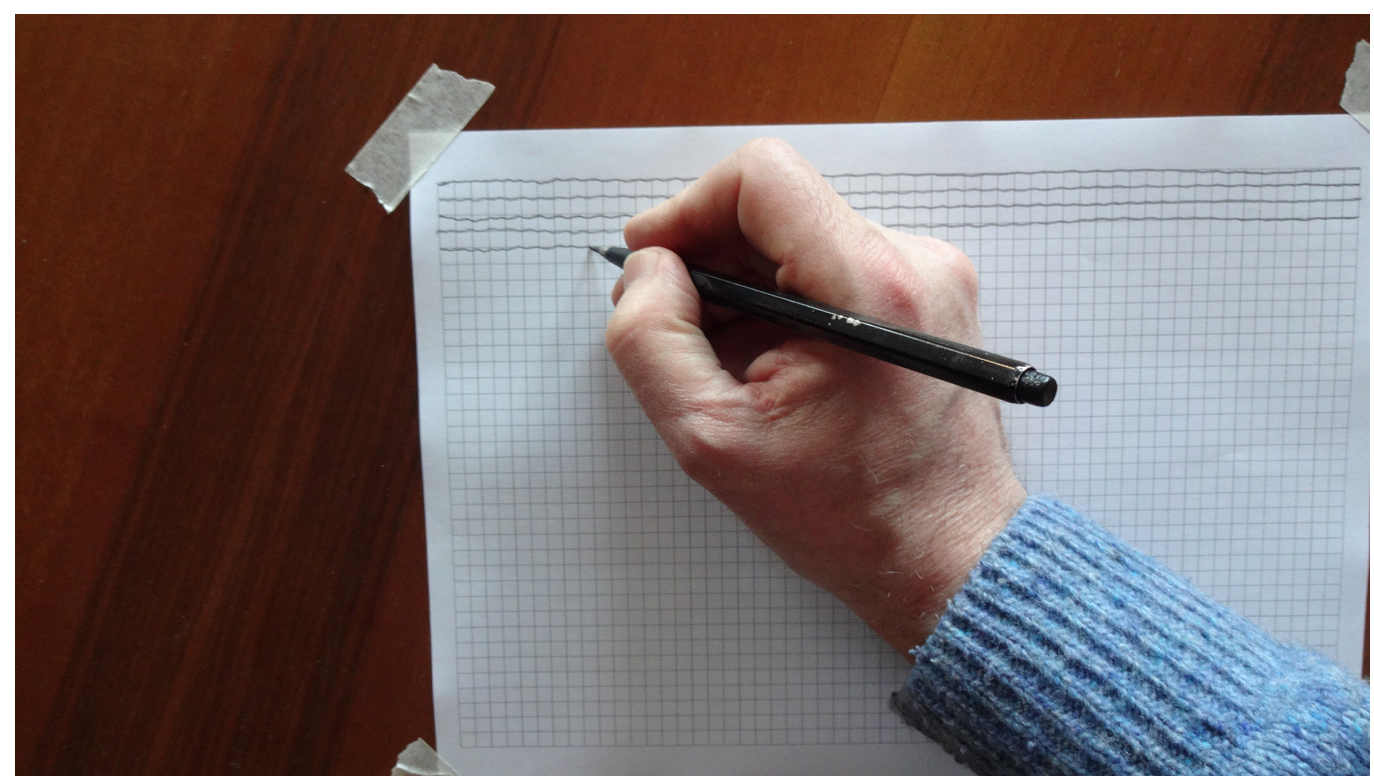

The exercises should be performed with both hands, once with the right and once with the left. The fact that one is right or left-handed is therefore irrelevant. However, the general purpose is not to train ambidextrous draftsmen but simply to get our body used not to create lazy parts. This gives the opportunity either consciously or indifferently to decide which side to involve to and to express ourselves by drawing.

We will start with a series of drawings with constrained lines: pre-printed lines to be followed with the gaze and hand together.This exercise is conceived to force the hand to get used to the regular, rectilinear or curvilinear extension, and involuntarily all the movements will be acquired and will settle in the body. Subsequently, we will move on to a series of drawings with lines in the "open field", that is, the tracing of the same grids by means of the 
presence of a few references. In this way the attention will be diverted from a specific area to a larger one.

To see in detail the first of these exercises, let's put ourselves in the conditions of a teacher who works side by side with a student.

Let's wash our hands and dry them. Let's sit on a solid chair, placed in front of an empty desk. Let's take a $80 \mathrm{~g} / \mathrm{m} 2$ ISO A4 sheet $(21 \times 29.7 \mathrm{~cm})$ with $5 \mathrm{~mm}$ side-squares onto; let's place it in front of us horizontally (landscape) and let's fix it by the edges to the table with gummed paper (opaque beige scotch). If the surface is rough or too hard, we can put cardboard or other sheets beneath it. For no reason the sheet must be moved. The squared sheet will serve for the early exercises and will facilitate the tracing of parallel and perpendicular lines. Later, we will use blank sheets and then $120 \mathrm{~g} / \mathrm{m} 2$ smooth drawing sheets that will allow us to refine the precision.

By convention, we will perform the exercises first with the right hand and then with the left one; only after mastering the movements, we can decide which hand to start with.

Let's take a wooden pencil or, better, a mechanical pencil, with a medium hard graphite (HB) and a sharpened tip. How to hold it? The part of the tip must be resting on the midpoint of the last phalanx of the middle finger and be held simultaneously by the fingertips of the index and thumb. The pencil must come out of the hand (towards the back) resting on the phalanx of the palm just below the knuckle of the index finger, halfway between thumb and forefinger. The tip will protrude about $2 \mathrm{~cm}$ off the fingers.

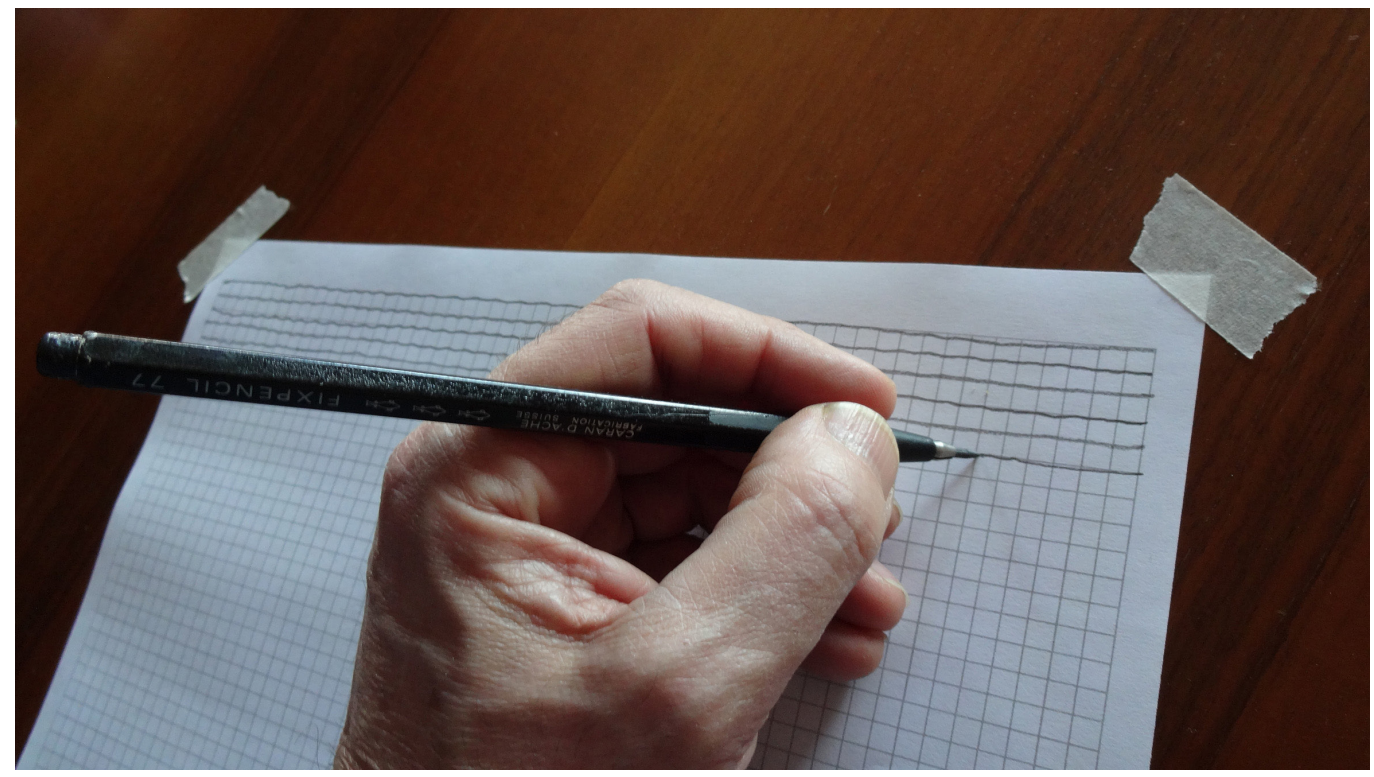

When drawing, posture is as fundamental as when playing the piano, the lute, the guitar, or eating. We position ourselves with the torso erect, neither approaching the sheet with the head, nor arching the spine towards the sheet.

The best tracing is centrifugal, as when writing, and this is to ensure that the hand does not rub the sheet on the line just drawn. However, the position of the hand must also facilitate the observation of the line being drawn, both in the traced part and in the part still to be drawn. This condition is not always achievable and therefore the wrist must be oriented in order to find a compromise useful for the best observation. In tracing with very pointed mines (especially for hard ones) we could find ourselves in the condition of having to draw a line in the opposite direction to the centrifugal one, and therefore we would find ourselves with the tip in the tendency to puncture the sheet. In this case, the rotation of the wrist can 
provide us with a better position to visually control the straight line we are tracing on and, at the same time, to avoid sticking the mine.

Especially with softer mines, the hands must always be clean and dry in order not to scatter graphite as it passes over other marks. In some cases, it is advisable to use a second sheet as a mobile support beneath the hand in order to avoid unwanted stains.

Let's start with the horizontal lines, the simplest tracing. We start from the top left corner and trace the first line to the right; we go $5 \mathrm{~mm}$ down and trace the next in the reverse direction, from right to left, and so on until the sheet is completed.

Let's focus on the vertical lines. Always starting from the upper left corner, we trace the first line downwards; we move $5 \mathrm{~mm}$ to the right and trace the second line in the opposite direction, from bottom upwards; and so on until the sheet is completed.

Each line must be entirely covered trying not to detach the tip from the sheet.The pressure must be constant and the trend continuous and straight, not fast or slow but constant. We must dedicate to following the printed lines and not looking at the tip, that is, trying to focus on the line we are tracing.

After each finished line, we have to rotate the pencil slightly. This operation will help to maintain a spherical termination in the pencil tip which will make the marks of a constant thickness for longer. However, sharpening the pencil can be necessary once in while.

After this, let's put a new sheet and change hand. Now with the left, all mirrored: horizontal from the top right corner, from right to left, and so on, reversing the direction of each line. Always vertical from the top right corner, from top to bottom and following by reversing direction. By repeating these operations several times, we will realize that the lines will tend to be closer to the printed ones; they will also be more uniform and less flickering. It is time to move on to the blank sheets.

This sort of prelude to drawing as a gym for the body and mind, with all the physical and mental discipline it requires, is only an excerpt of a series of exercises the authors are currently working on in order to keep away the students (and not only) from their comfort zone, help them free themselves from the dependence of laterality and get used to face any question in lateral, divergent, creative terms, just as an architect should.

Let's not trivialize

As Di Napoli [Di Napoli 2004] explains, drawing has an intercultural, interlinguistic and symbolic dimension which is the result of discretization and a synthesis of the complexity of thought. Each act of observation of reality or ideation has the representation of its characterizing aspects as its next moment. Through the eyes one perceives the sign that turns again into thought and through the drawing the mind generates images and establishes an iterative flow of 'dreams' and 'signs': a continuous flow which one must experience the emotional sensation of the flowing in a non-purposeful way, like the actions of a child who simply imitates adults. As Goleman [Goleman 1996, p. 155] suggests:"Being able to enter the flow is the maximum expression of emotional intelligence; the flow represents perhaps the highest level of harnessing and exploitation of emotions at the service of performance and learning". The exercise proposed to develop 'counter-laterality', in its elementary simplicity and in the resistance and difficulty students finds in it, implicitly demonstrates the negative effects of a standardizing environment which is shaped according to the 'winning' algorithm. Drawing with the 'other' hand is not a marginal operation and promotes an involuntary acquisition of a cognitive flow that trains our brain to shift the cognitive balance also in emotional terms, thus becoming more "inclusive" to environment. And as Perkins says: "the solutions surprise because they involve very often from an oasis of false promise [...] towards a solution of a type very different from the expected" [Perkins 200I, p. 88] [I].

\section{Notes}

[I] The paper results of the collegial work of both the authors. The first two paragraphs were edited by Colonnese while Carpiceci did the rest. 


\section{References}

Braghieri Nicola (20I3). Architettura, arte retorica. Genova: Sagep Editori.

Cropley Arthur (2006). In praise of convergent thinking. In Creativity Research Journal, I 8, pp. 39 I-404.

De Bono Edward (1998). Creatività e pensiero laterale. Milano: Rizzoli.

Di Napoli Giuseppe (2004). Disegnare e conoscere. Torino Einaudi.

Galimberti Umberto (1999). Psiche e techne. L'uomo nell'età della tecnica. Bologna: Feltrinelli.

Goleman Daniel (1996). Intelligenza emotiva. Milano: Rizzoli.

Guilford Joy Paul (1959). Traits of creativity. In Anderson Harold Homer, Creativity and its Cultivation. New York: Harper, pp. I 42 - I 6 I.

Kuhn Thomas S. (1995). La struttura delle rivoluzioni scientifiche. Torino: Einaudi.

Perkins David (200 I). Come Leonardo. Milano: II Saggiatore.

\section{Authors}

Marco Carpiceci, Sapienza Università di Roma, marco.carpiceci@uniromal .it

Fabio Colonnese, Sapienza Università di Roma, fabio.colonnese@uniromal.it

To cite this chapter. Carpiceci Marco, Colonnese FAbio (2020). Laterale vs algoritmico: un nuovo (vecchio) ruolo per il disegno?/Lateral vs algorithmic: a new (old) role for drawing? In Arena A., Arena M., Brandolino R.G., Colistra D., Ginex G., Mediati D., Nucifora S., Raffa P. (a cura di). Connettere. Un disegno per annodare e tessere. Atti del $42^{\circ}$ Convegno Internazionale dei Docenti delle Discipline della Rappresentazionel Connecting. Drawing for weaving relationships. Proceedings of the 42th International Conference of Representation Disciplines Teachers. Milano: FrancoAngeli, pp. 260-275. 